\title{
REINVESTIGATION OF THE TAXONOMY OF CLOSTRIDIUM BIFERMENTANS AND CLOSTRIDIUM SORDELLII
}

\author{
S. Nakamura, T. Shimamura, H. Hayashi and S. Nishida \\ Department of Bacteriology, School of Medicine, Kanazawa University, Kanazawa, Japan
}

\begin{abstract}
THE taxonomic relationship between Clostridium bifermentans and C. sordellii has been well reviewed by Brooks and Epps (1958) and was subsequently studied by Nishida, Tamai and Yamagishi (1964). In view of Novotonýs recent claim (1969) that both species should be classified on the basis of sugar components in the cell walls, and because of the similarity of both species in their cultural and biochemical properties, the problem was reinvestigated in the present study by means of numerical taxonomy and consideration of DNA-DNA homology, thermostability of homologous and heterologous duplexes, and analysis of sugar components in the cell walls.
\end{abstract}

\section{MATERIALS AND METHODS}

Strains used. The sources and designations of the strains are shown in table I.

C. sordellii strain 82 was obtained from the Department of Bacteriology, Leeds University, in 1959; at that time, the strain was non-toxigenic and urease negative. The subsequent subculture of this strain stocked in cooked-meat broth is designated as strain 82-Kanazawa $(82-\mathrm{KZ})$ in the present text. Strains 82-SJ2, 82-SJ3, and 82-SJ4 are the substrains of C. sordellii strain 82 stocked in Leeds University by single-cell isolation (Huang, 1959). A culture of $C$. sordellii strain 82 was also received from Dr A. R. Prévot, Pasteur Institute, Paris, in 1963; this strain is still toxigenic and urease positive and is designated as $C$. sordellii no. 82-Pasteur (82-P). C. sordellii no. $7222 \mathrm{R} / 100$ is a non-toxigenic substrain obtained by heating the toxigenic $C$. sordellii strain $7222 \mathrm{R}$ at $100^{\circ} \mathrm{C}$ for $30 \mathrm{~min}$. C. sordellii no. $1734 / 90$ is another non-toxigenic substrain obtained by heating a toxigenic strain 1734 at $90^{\circ} \mathrm{C}$ for 30 min. (Huang, Tamai and Nishida, 1965).

Numerical taxonomy. The properties used in the characterisation of the organisms were previously described by Nakamura et al. (1973). The substrates used for tests of deaminase activity are alanine, aspartate, arginine, glutamate, leucine, methionine, phenylalanine, serine, threonine, and valine. The number of features scored is 162. Procedures for the determination of the strain characteristics, similarity value (S-value), coding of data, and analysis of the S-value have been described previously (Nakamura et al., 1973).

Determination of sugar components of cell walls. Paper chromatography with Toyo filter-paper no. 51 was used according to the method described by Cummins and Johnson (1971). The bacterial cells were cultured in PY medium containing $1 \%$ fructose (PYF medium). The PY medium consisted (w/v) of proteose peptone (Difco No. 2) $2 \%$, yeast extract (Daigo, Tokyo, Japan) $0.5 \%, \mathrm{NaCl} 0.5 \%$, and sodium thioglycollate $0.1 \%$. The culture was harvested usually in the late logarithmic phase.

Growth inhibition by mannose. Volumes $(0 \cdot 1 \mathrm{ml})$ of 12 -h cultures grown in the PY medium with $0.5 \%$ fructose were transferred into $10-\mathrm{ml}$ volumes of the PY medium with or without $1 \%$ mannose and incubated at $37^{\circ} \mathrm{C}$. Bacterial growth was measured for optical density at

Received 15 Aug. 1974; accepted 14 Oct. 1974.

J. MED. MICROBIOL.-VOL. 8 (1975) 
TABLE I

Sources and designations of organisms employed in numerical taxonomy and DNA reassociation studies

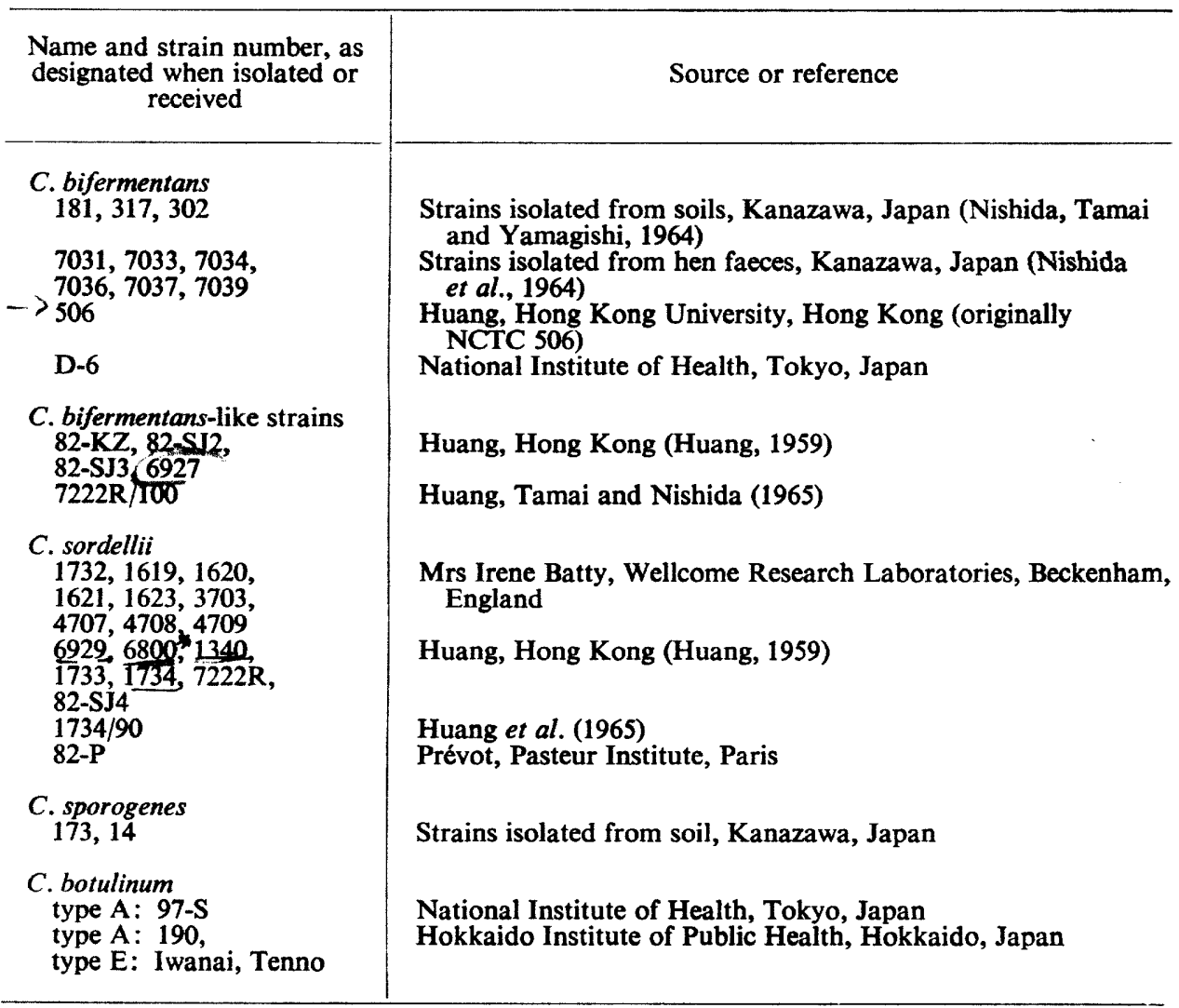

$560 \mathrm{~nm}\left(E_{560}\right)$ with a Shimazu-Bosch-Lomb Spectronic 20 spectrophotometer (Shimazu Co. Kyoto, Japan) after incubation for $12,24,48$, and $72 \mathrm{~h}$. The $p \mathrm{H}$ values of cultures were measured with a Zeromatic SS-3 pH meter (Beckman-Toshiba Ltd, Tokyo, Japan) at the final harvest time.

Preparation of DNA. The cells were grown in the PYF medium. For preparation of ${ }^{3} \mathrm{H}$-labelled DNA, $10 \mu \mathrm{Ci}$ of ${ }^{3} \mathrm{H}$-thymidine was added to $100 \mathrm{ml}$ of PYF medium without yeast extract. Penicillin $\mathrm{G}$ was added to a concentration of $50 \mu \mathrm{g}$ per $\mathrm{ml}$ in the late logarithmic phase. The culture was incubated for $30 \mathrm{~min}$. at $37^{\circ} \mathrm{C}$ with further incubation for $10 \mathrm{~min}$. at $60^{\circ} \mathrm{C}$. The treated cells were then harvested by centrifugation, and suspended in $0.15 \mathrm{M}-\mathrm{NaCl}$ solution containing $0.01 \mathrm{M}$-ethylenediamine tetraacetic acid (EDTA) at $p \mathrm{H} \mathrm{8.0}$. The cell preparation was stored at $-25^{\circ} \mathrm{C}$ and thawed when used. The cell suspension was treated with lysozyme $1 \mathrm{mg}$ per $\mathrm{ml}$ and lysed with $3 \%$ sodium lauryl sulphate (SLS). Extraction of DNA from this lysate was performed according to the method of Marmur (1961).

DNA homology studies. The competition test with membrane filter was performed according to the method described by Johnson and Ordal (1968) and Johnson and Cummins (1972). Ten $\mu$ l of labelled DNA fragments (1.0 $\mu \mathrm{g}$ DNA) homologous to the DNA on the filter (reference DNA) and $100 \mu \mathrm{l}$ of 2.2-strength salt-sodium citrate (SSC) solution (SSC consists of $0.15 \mathrm{M}-\mathrm{NaCl}$ and $0.015 \mathrm{M}$-sodium citrate at $p \mathrm{H} \mathrm{7.0)}$ or competitor DNA (75 $\mu \mathrm{g}$ usually and 


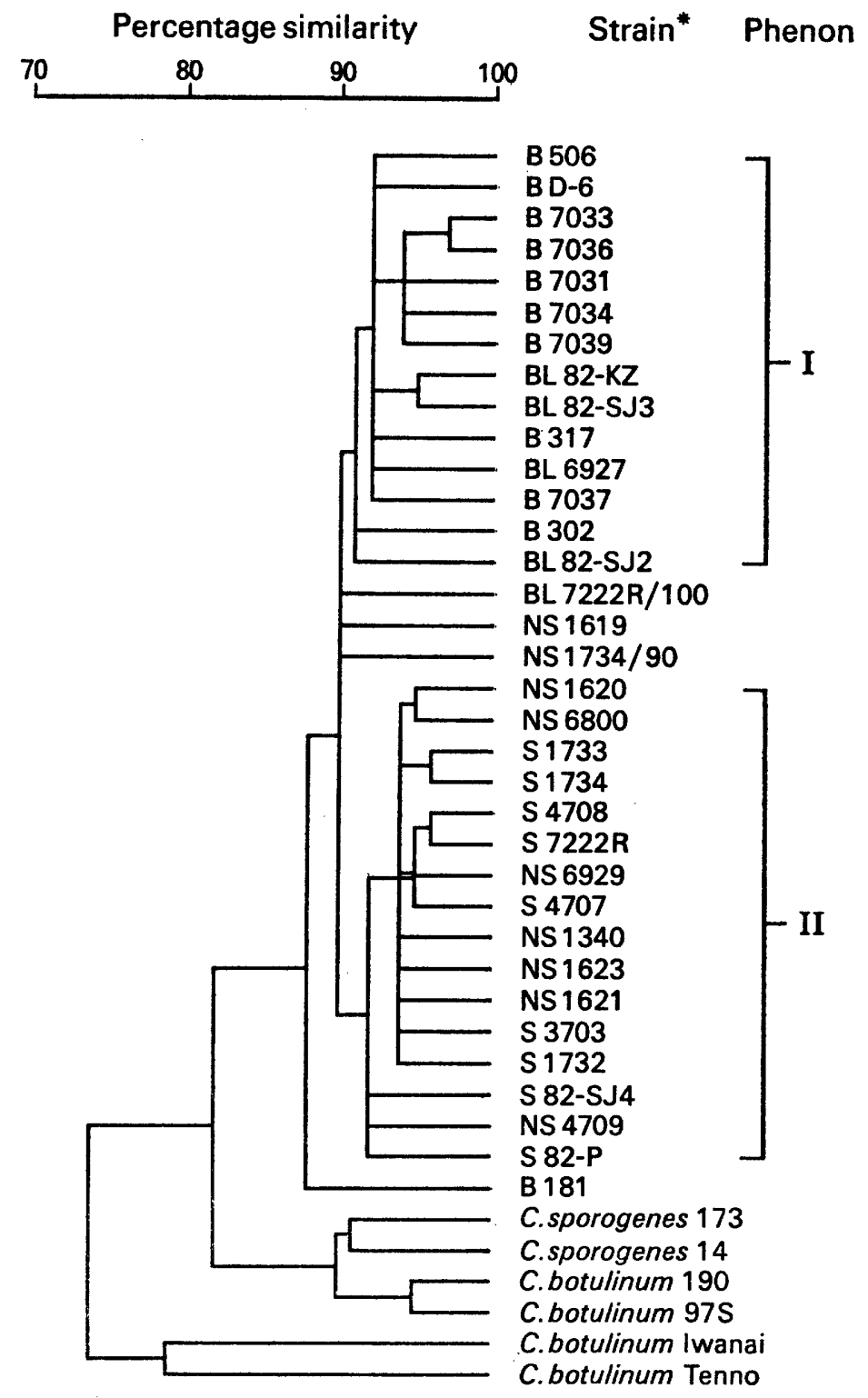

Fig. 1.-Dendrogram of $C$. bifermentans, $C$. sordellii, and reference strains. ${ }^{*} \mathrm{~B}=C$. bifermentans; $\mathrm{BL}=C$. bifermentans-like strain; $\mathrm{S}=$ toxigenic $C$. sordellii; $\mathrm{NS}=$ non-toxigenic $C$. sordellii. 


\section{TABLE II}

Mean similarities of each phenon-II strain (C. sordellii) to other strains in the same phenon (II) and to all strains in another phenon (I)

\begin{tabular}{l|cc}
\hline \multirow{2}{*}{$\begin{array}{c}\text { Strain in } \\
\text { phenon II }\end{array}$} & \multicolumn{2}{|c}{ Mean similarity value (\%) to } \\
\cline { 2 - 2 } phenon I & phenon II \\
C. sordellii & & \\
1734 & & 86 \\
1620 & 84 & 90 \\
1621 & 83 & 89 \\
6800 & 83 & 89 \\
3703 & 83 & 89 \\
1733 & 81 & 90 \\
6929 & 81 & 92 \\
$7222 \mathrm{R}$ & 81 & 92 \\
1732 & 80 & 89 \\
1623 & 80 & 91 \\
4709 & 80 & 89 \\
1340 & 80 & 87 \\
4707 & 79 & 90 \\
$82-S J 4$ & 79 & 89 \\
4708 & 78 & 90 \\
$82-\mathrm{P}$ & 78 & 88 \\
\hline
\end{tabular}

$150 \mu \mathrm{g}$ occasionally) in 2.2-strength SSC were added to incubation vials ( 6 by $25 \mathrm{~mm}$ ). The size of the small filter was $3 \times 9 \mathrm{~mm}$. The vials were incubated for $15 \mathrm{~h}$ at $60^{\circ} \mathrm{C}$. After incubation, filters were washed in double-strength SSC at the temperature used for incubation, dried, and counted in a liquid scintillation system, Unilex I-A (Nuclear-Chicago Co., Des Plaines, Ill., USA).

Investigation of the thermostability of DNA duplexes. Homologous or heterologous DNA duplexes on filters were formed by the above-mentioned procedure. The filters washed in double-strength SSC were transfixed with an insect pin and placed in a Wassermann tube $(13 \times 100 \mathrm{~mm})$ containing $1.2 \mathrm{ml}$ of 0.5 -strength SSC; the tube was then placed in a water bath. The filters were transferred at 10-min. intervals through a series of tubes with $5^{\circ} \mathrm{C}$ temperature increments at each interval. The water bath reached each new temperature in approximately $5 \mathrm{~min}$. Each tube was emptied into a scintillation vial and washed in with $0.5 \mathrm{ml}$ of 0.5 -strength SSC, and then $10 \mathrm{ml}$ of a preparation of Triton X-100 counting solution ( 3 parts toluene counting solution and 2 parts Triton $X-100$ ) was added to each vial which was finally transferred to a liquid scintillation counter.

TABLE III

Some biochemical criteria differentiating phenon I from phenon II

\begin{tabular}{|c|c|c|c|c|c|c|c|c|c|c|}
\hline \multirow{3}{*}{ Phenon } & \multirow{3}{*}{$\begin{array}{c}\text { Number } \\
\text { of } \\
\text { strains } \\
\text { included }\end{array}$} & \multicolumn{9}{|c|}{ Number of strains giving a positive result in tests for } \\
\hline & & \multicolumn{2}{|c|}{ fermentation of } & \multirow{2}{*}{$\begin{array}{c}\text { growth } \\
\text { inhibition } \\
\text { by } \\
\text { mannose* }\end{array}$} & \multirow[t]{2}{*}{ phosphatase } & \multirow[t]{2}{*}{ urease } & \multicolumn{3}{|c|}{ deaminase for } & \multirow{2}{*}{$\begin{array}{c}\text { toxi- } \\
\text { genicity }\end{array}$} \\
\hline & & mannose & sorbitol & & & & arginine & valine & $\widehat{\text { alanine }}$ & \\
\hline I & 14 & $12^{*}$ & 13 & 0 & 8 & 0 & 14 & 7 & 8 & $\mathbf{0}$ \\
\hline II & 16 & 1 & 1 & 15 & 0 & 16 & 1 & 0 & 0 & 9 \\
\hline
\end{tabular}

- See Methods and table IV. 


\section{RESULTS}

Eighteen toxigenic and non-toxigenic strains of $C$. sordellii, 11 strains of $C$. bifermentans and $5 C$. bifermentans-like strains that are labelled as $C$. sordellii but are non-toxigenic and urease negative were used for this study. As presented in fig. 1, all of these strains are linked at a high S-value $(88 \%)$ and associated at a low S-value $(82 \%)$ with reference strains of $C$. sporogenes and $C$. botulinum type A. The strains in the 88-phenon were sorted into two groups, phenons I and II at an S-value of $91 \%$. Phenon I included C. bifermentans and the $C$. bifermentans-like strains, whilst phenon II incorporated

TABLE IV

Inhibition of growth of certain organisms by mannose

\begin{tabular}{|c|c|c|c|c|c|}
\hline \multicolumn{2}{|c|}{ Organism } & \multicolumn{2}{|c|}{$\begin{array}{l}\text { Optical density }\left(E_{560}\right) \text { of culture } \\
\text { at } 24 \mathrm{~h} \text { in medium* }\end{array}$} & \multicolumn{2}{|c|}{$\begin{array}{l}p \mathrm{H} \text { value after culture for } 72 \mathrm{~b} \\
\text { in medium* }\end{array}$} \\
\hline & & PY & PYM & PY & PYM \\
\hline $\begin{array}{c}\text { Phenon I } \\
506 \\
\text { D-6 } \\
7033 \\
7036 \\
7031 \\
7034 \\
7039 \\
82-\mathrm{KZ} \\
82-\mathrm{SJ} 3 \\
317 \\
6029 \\
7037 \\
302 \\
82-\mathrm{SJ} 2\end{array}$ & $\begin{array}{l}\text { (B) } \dagger \\
\text { (B) } \\
\text { (B) } \\
\text { (B) } \\
\text { (B) } \\
\text { (B) } \\
\text { (B) } \\
\text { (BL) } \\
\text { (BL) } \\
\text { (B) } \\
\text { (BL) } \\
\text { (B) } \\
\text { (B) } \\
\text { (BL) }\end{array}$ & $\begin{array}{l}0.48 \\
0.34 \\
0.26 \\
0.30 \\
0.40 \\
0.33 \\
0.37 \\
0.57 \\
0.47 \\
0.34 \\
0.55 \\
0.40 \\
0.54 \\
0.47\end{array}$ & $\begin{array}{l}1.24 \\
0.58 \\
0.96 \\
0.96 \\
0.80 \\
0.89 \\
1.05 \\
1.30 \\
1.22 \\
1.18 \\
1.16 \\
0.90 \\
1.05 \\
1.10\end{array}$ & $\begin{array}{l}8.07 \\
7.84 \\
8 \cdot 10 \\
8.02 \\
8.70 \\
8.07 \\
8.00 \\
8 \cdot 10 \\
7.98 \\
8 \cdot 12 \\
8.09 \\
8.00 \\
8.04 \\
7.87\end{array}$ & $\begin{array}{l}5.52 \\
6.52 \\
5.43 \\
5.30 \\
5.47 \\
5.34 \\
5.38 \\
5.70 \\
5.58 \\
5.54 \\
5.61 \\
5.42 \\
6.55 \\
5.95\end{array}$ \\
\hline $\begin{array}{c}\text { Phenon II } \\
1620 \\
6800 \\
1733 \\
1734 \\
4708 \\
7222 \mathrm{R} \\
6929 \\
4707 \\
1340 \\
1623 \\
1621 \\
3703 \\
1732 \\
82-\mathrm{SJ} 4 \\
4709 \\
82-\mathrm{P}\end{array}$ & $\begin{array}{l}\text { (NS) } \\
\text { (NS) } \\
\text { (S) } \\
\text { (S) } \\
\text { (S) } \\
\text { (S) } \\
\text { (NS) } \\
\text { (S) } \\
\text { (NS) } \\
\text { (NS) } \\
\text { (NS) } \\
\text { (S) } \\
\text { (S) } \\
\text { (S) } \\
\text { (NS) } \\
\text { (S) }\end{array}$ & $\begin{array}{l}0.44 \\
0.42 \\
0.29 \\
0.21 \\
0.32 \\
0.28 \\
0.69 \\
0.31 \\
0.54 \\
0.41 \\
0.49 \\
0.48 \\
0.31 \\
0.49 \\
0.53 \\
0.29\end{array}$ & $\begin{array}{l}0.05 \\
0.25 \\
0 \cdot 30 \\
0 \cdot 10 \\
0 \cdot 10 \\
0 \cdot 15 \\
0.50 \\
0.05 \\
0 \cdot 22 \\
0.09 \\
0 \cdot 23 \\
0.31 \\
0.01 \\
0.04 \\
0 \cdot 10 \\
0.05\end{array}$ & $\begin{array}{l}8.00 \\
7.99 \\
7.92 \\
7.90 \\
7.94 \\
8.05 \\
8.00 \\
7.86 \\
7.90 \\
8.00 \\
8.05 \\
8.04 \\
8.02 \\
8.02 \\
8.02 \\
8.04\end{array}$ & $\begin{array}{l}7 \cdot 60 \\
7 \cdot 71 \\
7 \cdot 57 \\
7 \cdot 82 \\
7 \cdot 60 \\
7 \cdot 81 \\
7 \cdot 74 \\
7 \cdot 44 \\
7 \cdot 70 \\
7 \cdot 64 \\
7 \cdot 70 \\
7 \cdot 57 \\
7 \cdot 40 \\
7 \cdot 56 \\
7 \cdot 38 \\
7 \cdot 50\end{array}$ \\
\hline $\begin{array}{c}\text { 90-phenon } \\
7222 \mathrm{R} / 100 \\
1619 \\
1734 / 90\end{array}$ & $\begin{array}{l}\text { (BL) } \\
\text { (NS) } \\
\text { (NS) }\end{array}$ & $\begin{array}{l}0.62 \\
0.47 \\
0.37\end{array}$ & $\begin{array}{l}1 \cdot 15 \\
0.07 \\
0.38\end{array}$ & $\begin{array}{l}8 \cdot 05 \\
8 \cdot 00 \\
8 \cdot 10\end{array}$ & $\begin{array}{l}5.53 \\
7.58 \\
7.78\end{array}$ \\
\hline
\end{tabular}

* $\mathrm{PY}=$ peptone yeast-extract medium; PYM = PY medium with mannose (1\%) (see Methods).

$\dagger \mathrm{B}=$ C.bifermentans; $\mathrm{BL}=$ C. bifermentans-like strain; $\mathrm{S}=$ toxigenic $C$. sordellii; $\mathrm{NS}=$ nontoxigenic $C$. sordellii. 
the toxigenic and non-toxigenic strains of $C$. sordellii. In table II, the mean S-value of each strain of phenon II for all other strains in the same phenon is compared with its mean S-value for all strains in phenon I. Although the results suggest that both phenons are extremely close to each other, characteristics that differentiate the strains in phenon I from the strains in phenon II were fermentation of mannose and sorbitol, urease activity, arginine deamination, and growth inhibition by mannose (table III). Mannose enhanced the growth of strains in phenon I, but inhibited the growth of strains in phenon II when present at a concentration of $1 \%$ in PY culture medium. The results

TABLE V

Cell-wall sugars of Clostridium sordellii and C. bifermentans

\begin{tabular}{|c|c|c|c|c|}
\hline \multirow{2}{*}{ Strain number } & \multicolumn{4}{|c|}{ Cell-wall sugars present $(+)$ or absent $(-)^{*}$} \\
\hline & galactose & glucose & mannose & rhamnose \\
\hline \multicolumn{5}{|l|}{ C. sordellii } \\
\hline $\begin{array}{l}1733 \\
1734\end{array}$ & + & + & - & - \\
\hline $\begin{array}{l}1734 \\
4707\end{array}$ & $\overline{-}$ & ++ & $\overline{-}$ & - \\
\hline 4708 & $z$ & $\begin{array}{l}\text { Ir } \\
+\end{array}$ & - & $\bar{z}$ \\
\hline 3703 & + & + & - & - \\
\hline 82-P & tr & ++ & - & - \\
\hline $\begin{array}{l}82-S J 4 \\
1623\end{array}$ & $\bar{t}$ & ++ & - & $\overline{-}$ \\
\hline $\begin{array}{l}1623 \\
1340\end{array}$ & tr & tr & - & - \\
\hline 1619 & - & + & - & - \\
\hline 1620 & - & ++ & - & - \\
\hline 6800 & $\operatorname{tr}$ & $\operatorname{tr}$ & - & - \\
\hline 6929 & + & + & - & - \\
\hline 1621 & tr & ++ & - & - \\
\hline 4709 & $\underline{\operatorname{tr}}$ & $\begin{array}{c}\text { tr } \\
++\end{array}$ & Z & $\overline{-}$ \\
\hline $1222 \mathrm{R}$ & - & $\begin{array}{l}++ \\
++\end{array}$ & $\overline{-}$ & - \\
\hline $1734 / 90$ & $\operatorname{tr}$ & ++ & - & - \\
\hline \multicolumn{5}{|l|}{ C. bifermentans } \\
\hline $\begin{array}{l}302 \\
506\end{array}$ & 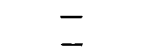 & ++ & ++ & ++ \\
\hline 317 & - & $\stackrel{+}{+}$ & $\stackrel{+}{+t}$ & \pm \\
\hline 181 & + & + & + & + \\
\hline 7031 & + & ++ & ++ & - \\
\hline $\begin{array}{l}7033 \\
7034\end{array}$ & + & + & + & - \\
\hline $\begin{array}{l}7034 \\
7036\end{array}$ & + & $\begin{array}{l}+ \\
+\end{array}$ & $\begin{array}{l}\text { tr } \\
+\end{array}$ & - \\
\hline 7037 & + & + & + & - \\
\hline $\begin{array}{l}7039 \\
D-6\end{array}$ & + & ++ & + & 5 \\
\hline D-6 & + & tr & + & $+t$ \\
\hline \multicolumn{5}{|l|}{$\begin{array}{l}\text { C. bifermentans- } \\
\text { like strains }\end{array}$} \\
\hline $82-\mathrm{KZ}$ & $+t$ & ++ & - & - \\
\hline $\begin{array}{l}\text { 82-SJ2 } \\
82-S J 3\end{array}$ & - & + & - & - \\
\hline $\begin{array}{l}\text { 82-SJ3 } \\
7222 / 100\end{array}$ & $=$ & $\begin{array}{l}++ \\
++\end{array}$ & $\begin{array}{l}++ \\
++\end{array}$ & $\begin{array}{c}+ \\
++\end{array}$ \\
\hline 6927 & - & ++ & ++ & ++ \\
\hline
\end{tabular}

- $\mathrm{tr}=$ Trace;,+++ indicate the relative amounts present. 
are given in detail in table IV. Since maximal growth was reached at 12-24 h and lysis occurred thereafter, only the results at $24 \mathrm{~h}$ are shown in the table. Of the other 16 sugars tested, none showed a growth-inhibitory effect.

Table $\mathrm{V}$ summarises the results of our studies on the sugar components of cell walls of $C$. sordellii and $C$. bifermentans. Glucose was demonstrated in all but one of the strains examined. Neither mannose nor rhamnose was present in any strain of $C$. sordellii, whereas mannose was demonstrated in all strains of $C$. bifermentans tested and rhamnose was present in some. Five strains of $C$. bifermentans, viz., nos. 7031, 7033, 7034, 7037 and 7039, which consistently produced extraordinarily minute colonies with wide haemolytic zones on blood agar, had cell walls with glucose, mannose, and galactose but without rhamnose. Glucose and galactose were notably present and mannose and rhamnose were absent from the cell walls of the non-toxigenic, urease-negative strain $82-\mathrm{KZ}$, which originated from a toxigenic $C$. sordellii strain no. 82 ; the toxigenic $C$. sordellii strain $82-\mathrm{P}$, possibly of the same origin as strain $82-\mathrm{KZ}$, showed glucose and a trace of galactose in its cell wall. Strains $82-\mathrm{SJ} 2,82-\mathrm{SJ} 3$ and $82-\mathrm{SJ} 4$ are single-cell isolates derived from toxi-

TABLE VI

Polynucleotide sequence relationships between strains of phenons I and II

\begin{tabular}{|c|c|c|c|c|c|}
\hline \multirow{3}{*}{\multicolumn{2}{|c|}{ Organism }} & \multicolumn{4}{|c|}{ Data obtained in comparative tests with } \\
\hline & & \multicolumn{2}{|c|}{ strain 1620 (phenon II) } & \multicolumn{2}{|c|}{ strain 82-SJ2 (phenon I) } \\
\hline & & $\begin{array}{l}\text { Percentage } \\
\text { homology }\end{array}$ & $\Delta \operatorname{Tm}(\mathrm{e})$ & $\begin{array}{l}\text { Percentage } \\
\text { homology }\end{array}$ & $\Delta \operatorname{Tm}(\mathrm{e})$ \\
\hline $\begin{array}{c}\text { Phenon II } \\
1620 \\
1734 \\
82-S J 4 \\
1621 \\
4708 \\
1732 \\
6800 \\
7222 R \\
3703 \\
82-P\end{array}$ & $\begin{array}{l}\text { (S)* } \\
\text { (S) } \\
\text { (S) } \\
\text { (NS) } \\
\text { (NS) } \\
\text { (S) } \\
\text { (NS) } \\
\text { (S) } \\
\text { (S) } \\
\text { (S) }\end{array}$ & $\begin{array}{r}100 \\
100 \\
99 \\
97 \\
97 \\
96 \\
95 \\
94 \\
92 \\
88\end{array}$ & $\begin{array}{c}0 \\
\dddot{0} \\
\ldots \\
\ldots \ldots \\
0 \cdot 3 \\
0 \\
\ddot{0.4} \\
\ldots\end{array}$ & $\begin{array}{l}51 \\
52 \\
72 \\
72 \\
71 \\
72 \\
69 \\
69 \\
43 \\
55\end{array}$ & $\begin{array}{c}9 \cdot 5 \\
\dddot{9} \cdot 9 \\
\ldots \\
\dddot{9} \cdot 9 \\
10 \cdot 5 \\
\dddot{9} \cdot 9 \\
\ldots\end{array}$ \\
\hline $\begin{array}{c}\text { Phenon I } \\
\text { 82-KZ } \\
82-\mathrm{SJ3} \\
7034 \\
7037 \\
7033 \\
7039 \\
317 \\
82-\mathrm{SJ} 2\end{array}$ & $\begin{array}{l}\text { (BL) } \\
\text { (BL) } \\
\text { (B) } \\
\text { (B) } \\
\text { (B) } \\
\text { (B) } \\
\text { (B) } \\
\text { (BL) }\end{array}$ & $\begin{array}{l}71 \\
63 \\
62 \\
60 \\
57 \\
54 \\
51 \\
46\end{array}$ & $\begin{array}{c}\dddot{9 \cdot 8} \\
9 \cdot 7 \\
\ldots \\
\ldots \\
7.8 \\
8.8\end{array}$ & $\begin{array}{r}91 \\
100 \\
97 \\
99 \\
100 \\
100 \\
92 \\
100\end{array}$ & $\begin{array}{l}\dddot{0} \cdot 2 \\
0.5 \\
\cdots \\
\cdots \\
\dddot{2} \cdot 6 \\
0\end{array}$ \\
\hline $\begin{array}{c}\text { 90-Phenon } \\
1734 / 90 \\
7222 R / 100\end{array}$ & $\begin{array}{l}\text { (NS) } \\
\text { (BL) }\end{array}$ & $\begin{array}{l}99 \\
60\end{array}$ & $\ldots$ & $\begin{array}{l}69 \\
98\end{array}$ & $\ldots$ \\
\hline
\end{tabular}

* See footnote to table IV.

$+\ldots=$ Not tested. 
genic strain 82 but varying in their toxigenicity and urease activity; they also vary in their cell-wall sugar components. Glucose alone was found in strain 82-SJ2 which is non-toxigenic and urease-negative, and glucose alone was found in strain 82-SJ4 which is toxigenic and urease positive. Strain 82-SJ3 shows the typical properties of $C$. bifermentans; it is non-toxigenic, urease negative and has glucose, mannose and rhamnose in its cell wall.

The relationship between phenons I and II was further studied with DNADNA homology tests. Although strain 82-SJ2 in phenon I originated from C. sordellii strain 82 , strain $82-\mathrm{SJ} 2$ was used as the reference strain of phenon I because it exhibited the typical properties of $C$. bifermentans in cultural and biochemical tests and yet was linked by a high mean $\mathrm{S}$ value of $90 \%$ with strains in phenon II. The degree of DNA homology between strain 82-SJ2 of phenon I and each strain of phenon II ranged between 43 and $72 \%$, whilst

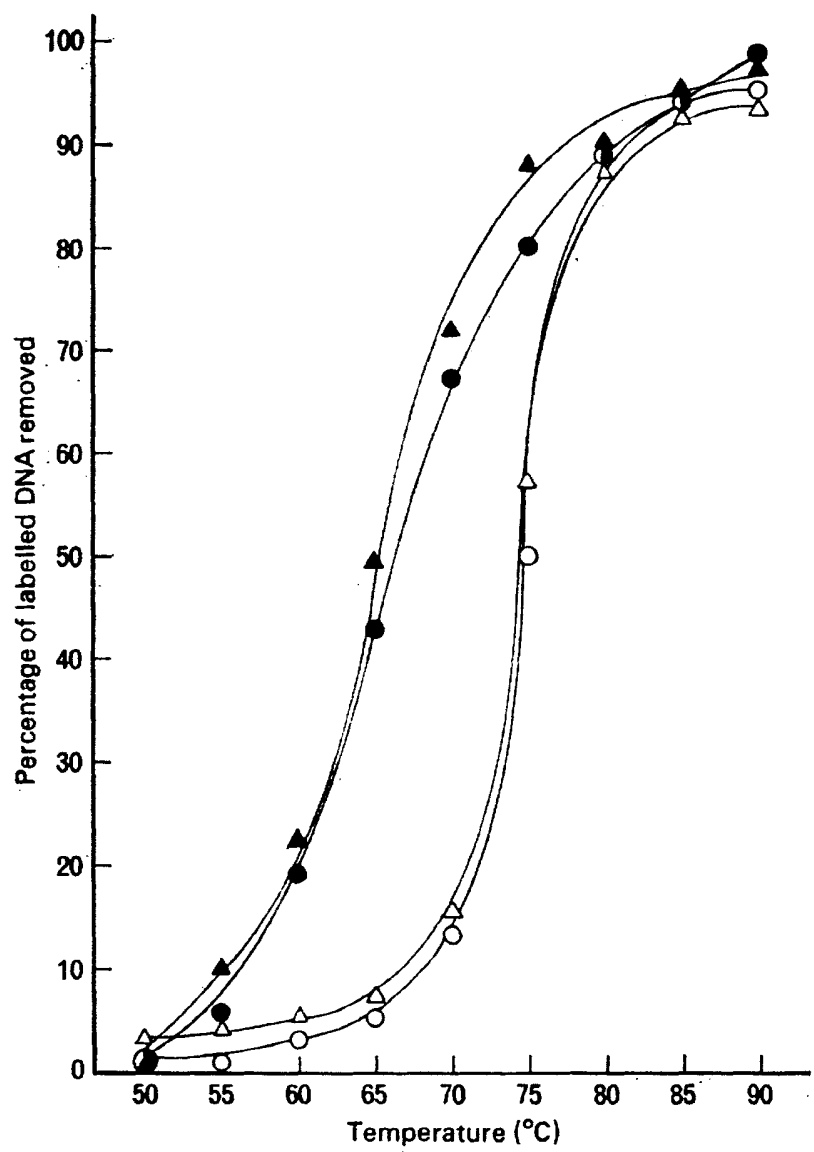

FIG. 2.-Thermo-stability profiles of homologous and heterologous duplexes of a strain 82-SJ2 of phenon I and a strain 1620 of phenon II. Strain 82-SJ2, ${ }^{3} \mathrm{H}$-DNA: $\triangle$ homologous, $\Delta$ heterologous; strain 1620, 3H-DNA: $O$ homologous, heterologous. The reassociations were porformed in double-strength $\mathrm{SSC}$ at $60^{\circ} \mathrm{C}$. The elution profiles were performed in half-strength SSC. 
the homology between strain 82-SJ2 and each strain of the same phenon ranged between 91 and $100 \%$ (table VI). Similar results were obtained when homology of the reference strain 1620 of phenon II was assessed in relation to the strains of phenons I and II. These findings indicate that although strains of both phenons-are intimately related they may still be differentiated.

Thermal stability tests were performed on the homologous DNA duplexes produced between strains of the same phenon and on the heterologous DNA duplexes formed between strains in different phenons. Fig. 2 depicts the homogolous and heterologous thermostability profiles of strains 82-SJ2 in phenon I and strain 1620 in phenon II both of which were employed as reference strains in the DNA-DNA homology experiment. The temperature differences between homologous and heterologous duplexes at which $50 \%$ of the duplexes disassociated $\{\operatorname{Tm}(\mathrm{e})\}$ are $9.5^{\circ} \mathrm{C}$ for strain 1620 which shows $51 \%$ homology with the strain $82-\mathrm{SJ} 2$, and $8.8^{\circ} \mathrm{C}$ for strain $82-\mathrm{SJ} 2$ which shows $46 \%$ homology with strain 1620 . The results summarised in table VI reveal that, in spite of the fairly wide degree of variation in DNA-DNA homology, approximately the same levels of $\Delta \operatorname{Tm}(\mathrm{e})$ could be obtained among strains of each phenon. The $\Delta \operatorname{Tm}(\mathrm{e})$ of the heterologous DNA duplexes ranged from $7.8^{\circ}$ to $10.5^{\circ} \mathrm{C}$, whereas those of the homologous DNA duplexes were less than $2 \cdot 6^{\circ} \mathrm{C}$. This finding again indicates that DNA preparations of strains within each phenon are highly homologous and that a certain difference exists between the two phenons.

\section{DisCUSSION}

Johnson (1973) defined geno-species including geno-subspecies and genovarieties on the basis of DNA-DNA homology. Geno-subspecies were strains having 60 to $70 \%$ homology with organisms in the homologous group. Our present findings reveal that $C$. bifermentans and $C$. sordellii can be allocated into one geno-species, since phenon I consisting of $C$. bifermentans and $C$. bifermentans-like strains and phenon II consisting of $C$. sordellii had degrees of homology ranging from 43 to $71 \%$ with each other. Besides, the DNA hetero-duplexes formed between strains of phenons I and II showed $\Delta \mathrm{Tm}(\mathrm{e})$ values ranging from $7 \cdot 8$ to $10.5^{\circ} \mathrm{C}$. However, these two groups were differentiated clearly from each other by the tests for urease, arginine deaminase, fermentation of sorbitol and mannose, and growth inhibition by mannose. Novotoný (1969), however, stated that two toxigenic strains of $C$. sordellii were urease negative. Also, fermentation of sugars is not a reliable criterion for differentiation when different culture media are employed (Tamai and Nishida, 1964). Novotoný (1969) advocated a classification based on distinction of cell-wall sugars; e.g., C. bifermentans has a pattern of glucose, rhamnose and mannose or galactose: and $C$. sordellii has a pattern of glucose only or glucose and a trace of galactose. However, Rode and Smith (1971) indicated that two of six C. bifermentans strains tested had glucose only and the remainder had multiple combinations of glucose, rhamnose and mannose or galactose. The present study revealed varying sugar patterns with sub-strains of a toxigenic $C$. sordellii strain 82 ; strain $82-\mathrm{SJ} 2$ in phenon I contained 
glucose only, and strain 82-SJ3, also in phenon I, had glucose, mannose, and rhamnose, whereas strain 82-SJ4 in phenon II had glucose only.

Strain 82 has given rise to several non-toxigenic substrains (Brooks and Epps, 1958). The cell wall of a non-toxigenic, urease-negative strain $82-\mathrm{KZ}$ contained glucose and galactose but no trace of rhamnose and mannose. The present results obtained with other strains disclosed that no definite pattern of cell-wall sugars could be found in either $C$. bifermentans or $C$. sordellii. In spite of the multiple sugar patterns, however, the present study demonstrates that the cell walls of both species were distinctly different in the mannose component, as stated by Novotoný (1969); mannose was consistently absent from the cell-wall preparations of all $18 \mathrm{C}$. sordellii strains, whilst it was present in all of the preparations of the 11 C. bifermentans strains tested.

The manner whereby mannose inhibits the growth of $C$. sordellii but not C. bifermentans is not obvious. If there is a correlation between growth inhibition by mannose and the absence of mannose in the cell wall, it remains to be elucidated.

The present findings suggest that a clear distinction may not be found between $C$. bifermentans and $C$. sordellii when an increased number of strains are tested. This assumption seems reasonable in view of the results obtained in the DNA homology test. It should be noted that Huang, Tamai and Nishida (1965) obtained a C. bifermentans-like substrain by heating a culture of a toxigenic single-cell isolate 82-SJ4 derived from a reference strain of $C$. sordellii.

In spite of their close relatedness, however, we still consider it significant that $C$. sordellii should be differentiated from $C$. bifermentans on the basis of a few phenetic differences that were closely related to the small difference in the homology of their polynucleotide sequences, because toxigenic strains are included among $C$. sordellii strains but not among the $C$. bifermentans group.

Recently, the same kind of findings were made by Lee and Riemann (1970) and by Kiritani et al. (1973) in studies of $C$. sporogenes and $C$. botulinum.

\section{SUMMARY}

The taxonomic relationships between Clostridium bifermentans and $C$. sordellii were reinvestigated by numerical taxonomy, studies of DNA-DNA homology and DNA duplex thermal stability, and by analysis of cell-wall sugar components. Although the results indicate that both species may be grouped into one geno-species, $C$. sordellii strains could be differentiated from C. bifermentans strains on the basis of a few phenetic criteria that include the inability to ferment mannose and sorbitol, the absence of mannose in the cell wall, the production of urease, the absence of arginine deaminase activity, and susceptibility to inhibition of growth by mannose.

We wish to thank Dr A. R. Prévot of the Pasteur Institute, Paris, for providing C. sordellii strain 82; and we are grateful to Dr L. DS. Smith, Dr C. S. Cummins and Dr J. L. Johnson, Anaerobe Laboratory, Virginia Polytechnic Institute and State University, Blacksburg, 
Virginia, USA, for their instructive advice on the techniques used in analysing cell-wall sugar components and in the detection of DNA-DNA homologies. We also thank Dr C. T. Huang, Hong Kong University, Hong Kong, for helpful comments.

\section{REFERENCES}

Brooks, M. E. AND Epps, H. B. G. 1958. Taxonomic studies of the genus Clostridium: Cl. bifermentans and Cl. sordellii. J. gen. Microbiol., 21, 144.

Cummins, C. S. AND Johnson, J. L. 1971. Taxonomy of the clostridia: wall composition and DNA homologies in Clostridium butyricum and other butyric acid-producing clostridia. J. gen. Microbiol., 67, 33.

HuANG, C. T. 1959. Comparison of Clostridium bifermentans and Clostridium sordellii. Ph.D. Thesis, University of Leeds, Leeds, England.

Huang, C. T., TAMAI, K. AND Nishida, S. 1965. Taxonomy of Clostridium bifermentans and Clostridium sordellii. III. Agglutinability of heat-resistant substrain of Clostridium sordellii. J. Bact., 90, 391.

Johnson, J. L. 1973. Use of nucleic-acid homologies in the taxonomy of anaerobic bacteria. Int. J. syst. Bact., 23, 308.

Johnson, J. L. AND CummIns, C. S. 1972. Cell wall composition and deoxyribonucleic acid similarities among the anaerobic coryneform, classical propionibacteria, and strains of Arachnia propionica. J. Bact., 109, 1047.

Johnson, J. L. AND ORdal, E. J. 1968. Deoxyribonucleic acid homology in bacterial taxonomy: effect of incubation temperature on reaction specificity. J. Bact., 95, 893.

Kiritani, K., Mitsui, N., Nakamura, S. AND Nishida, S. 1973. Numerical taxonomy of Clostridium botulinum and Clostridium sporogenes strains and their susceptibilities to induced lysins and to mitomycin C. Jap. J. Microbiol., 17, 361.

LEe, W. H. AND RIEMANN, H. 1970. The genetic relatedness of proteolytic Clostridium botulinum strains. J. gen. Microbiol., 64, 85 .

MARMUR, J. 1961. A procedure for the isolation of deoxyribonucleic acid from microorganisms. J. molec. Biol., 3, 208.

Nakamura, S., Shimamura, T., Hayase, M. AND Nishida, S. 1973. Numerical taxonomy of saccharolytic clostridia, particularly Clostridium perfringens-like strains; descriptions of Clostridium absonum sp. n. and C. paraperfringens. Int. J. syst. Bact., 23, 419.

Nishida, S., Tamal, K. AND Yamagishi, T. 1964. Taxonomy of Clostridium bifermentans and Clostridium sordellii. I. Their toxigenicity, urease activity and sporulating potency. J. Bact., 88, 1641.

Novotoný, P. 1969. Composition of cell walls of Clostridium sordellii and Clostridium bifermentans and its relation to taxonomy. J. med. Microbiol., 2, 81.

Rode, L. J. AND Smith, L. DS. 1971. Taxonomic implications of spore fine structure in Clostridium bifermentans. J. Bact., 105, 349.

TAMAI, K. AND NishidA, S. 1964. Taxonomy of Clostridium bifermentans and Clostridium sordellii. II. Toxigenic and sporulating potencies in substrains of Clostridium sordellii strain. J. Bact., 88, 1647. 